\title{
PENGARUH PEMBERIAN PUPUK URIN KAMBING YANG DIFERMENTASI TERHADAP PERTUMBUHAN DAN HASIL TANAMAN TOMAT (Lycopersicum esculentum Mill)
}

\section{THE EFFECT OF FERMENTED GOAT URINE FERTILIZER ON THE GROWTH AND YIELD OF TOMATO PLANT (Lycopersicum esculentum Mill)}

\author{
Visi Tinta Manik, Andi Budiansyah, Fitri Kurniati \\ Jurusan Agroteknologi Fakultas Pertanian Universitas Siliwangi \\ Korespondensi: visitintamanik@unsil.ac.id
}

\begin{abstract}
ABSTRAK
Tomat merupakan salah satu jenis tanaman sayuran yang memiliki nilai nutrisi cukup tinggi. Produksi tomat dari tahun ke tahun semakin meningkat sejalan dengan permintaan pasar. Untuk memenuhi permintaan tersebut, produksi tomat perlu ditingkatkan. Pupuk urin kambing yang difermentasi dapat digunakan untuk meningkatkan produksi tanaman tomat. Penelitian ini bertujuan untuk mengetahui efek pemberian pupuk urin kambing terhadap pertumbuhan dan hasil tanaman tomat. Penelitian ini menggunakan metode Rancangan Acak Kelompok (RAK) dengan enam perlakuan. Konsentrasi pupuk urin kambing yang digunakan adalah $0 \mathrm{ml} / \mathrm{l}, 150$ $\mathrm{ml} / \mathrm{l}, 175 \mathrm{ml} / \mathrm{l}, 200 \mathrm{ml} / \mathrm{l}, 225 \mathrm{ml} / \mathrm{l}$, dan $250 \mathrm{ml} / \mathrm{l}$. Parameter yang diuji meliputi tinggi tanaman, diameter batang, jumlah daun, dan bobot buah. Hasil penelitian ini menunjukkan bahwa pemberian pupuk urin kambing tidak memiliki pengaruh yang signifikan terhadap tinggi tanaman, diameter batang dan jumlah daun tanaman tomat. Namun, dapat meningkatkan bobot buah tomat secara signifikan dibandingkan dengan perlakuan tanpa penambahan pupuk urin kambing. Hal ini menunjukkan bahwa pemberian urin kambing dapat meningkatkan bobot buah tomat, sehingga berpotensi untuk meningkatkan produksi buah tomat.
\end{abstract}

Kata Kunci : tomat, pupuk, urin kambing

\begin{abstract}
Tomato is one of vegetable plant that has economic value and high nutritional content such as vitamin, mineral, protein, carbohydrate. Fermented goat urine fertilizer can be used to increase plant growth and crop production. This study aimed to determine the effect of fermented goat urine fertilizer on the growth and yield of tomato plant. The research method was used randomized block design consisting six treatments with quadruplicate. The concentration used in this study was $0 \mathrm{ml} / 1,150 \mathrm{ml} / 1,175 \mathrm{ml} / 1,200 \mathrm{ml} / \mathrm{l}, 225 \mathrm{ml} / \mathrm{l}$, and $250 \mathrm{ml} / \mathrm{l}$. Plant height, stem diameter, number of leaves, and fruit weight were observed in this study. The result showed that fermented goat urine had no significant effect on tomato plat height, diameter of stem, and number of leaves but has significant effect on fruit weight. Therefore fermented goat urine fertilizer has potential to increase tomato production.
\end{abstract}

Keywords: tomato, fermented, goat, urine

PENDAHULUAN

Tomat (Lycopersicum esculentum Mill) merupakan salah satu jenis tanaman sayuran yang termasuk kedalam family

Solanaceae. Buah tomat sangat bermanfaat bagi tubuh karena memiliki kandungan gizi 
yang tinggi (Cahyono, 2008). Buah Tomat mengandung berbagai makronutrien vitamin A, B, dan $\mathrm{C}$ cukup tinggi, dan beberapa mineral penting bagi tubuh (Canene-Adams et. al., 2004; Nasir et. al., 2015; Surbakti \& Berawi, 2016).

Sejak tahun 2015 hingga tahun 2018, produksi tomat terus mengalami peningkatan. Jumlah produksi tomat dari tahun 2015 hingga 2018 secara berturutturut adalah 877.792 ton, 883.223 ton, 962.845 ton, dan 976.77 ton per tahun (Kementrian Pertanian Republik Indonesia, 2019). Data tersebut mengindikasikan bahwa kebutuhan akan buah tomat terus meningkat, sehingga tomat menjadi salah satu komoditas yang menjanjikan secara ekonomi bagi para petani. Oleh karena itu untuk memenuhi kebutuhan masyarakat, produksi tomat perlu ditingkatkan.

Upaya peningkatan produksi tanaman dapat dilakukan dengan berbagai cara, salah satunya adalah pemilihan sumber nutrisi atau pupuk yang tepat. Tumbuhnya kesadaran para petani akan dampak negatif penggunaan pupuk kimia secara terusmenerus telah mendorong mereka untuk beralih dari pertanian konvensional ke pertanian organik. Pupuk organik merupakan bahan organik yang umumnya berasal dari hewan maupun tumbuhan yang ditambahkan kedalam tanah sebagai sumber hara (Sutanto,2002). Salah satu jenis pupuk organik adalah pupuk organik cair yang merupakan hasil pembusukan bahan-bahan organik yang berasal dari tanaman maupun hewan (Feses dan urin).

Urin kambing memiliki kandungan unsur hara paling tinggi dibandingkan dengan urin hewan ternak lainnya sehingga dapat digunakan sebagai pupuk organik cair. Selain memiliki kandungan hara yang cukup tinggi, pupuk organik cair dari urin kambing mudah larut dalam tanah sehingga mudah diserap oleh tanaman. Alvi et al., mengandung asam askorbat, solanine, likopen, saponin, karotenoid, polifenol,

(2018) membandingkan urin kambing, urin sapi, dan urin kelinci untuk pembibitan tanaman kelapa sawit. Hasilnya perlakuan urin kambing cenderung berpengaruh baik terhadap bobot kering tajuk, bobot kering akar, dan nisbah tajuk akar bibit kelapa sawit. Perlakuan pemberian urin kambing pada tanaman lada dapat meningkatkan pertumbuhan vegetative tanaman tersebut (Sarah et al.,2016).

Proses fermentasi dapat digunakan untuk mengolah urin kambing menjadi pupuk organik cair. Kandungan N, K, dan C-organik urin yang telah difermentasi lebih tinggi dibandingkan dengan urin yang belum difermentasi. Londra (2008) menyatakan kandungan $\mathrm{N}$ pada urin yang telah difermentasi meningkat dari $0.34 \%$ menjadi $0.89 \%$, kandungan $\mathrm{K}$, dan C-oranik juga meningkat cukup drastis.

Berdasarkan uraian diatas maka perlu dilakukan penelitian mengenai pengaruh urin kambing yang difermentasi terhadap pertumbuhan dan hasil tanaman tomat.

\section{METODE PENELITIAN}

Penelitian dilakukan dengan menggunakan metode eksperimen rancangan percobaan acak kelompok (RAK) terdiri dari 6 perlakuan dengan empat kali pengulangan. Benih tomat yang digunakan adalah varietas Servo F1. Sebanyak 15 liter urin kambing ditambah dengan 15 liter air kelapa kemudian difermentasi dengan penambahan EM4 sebanyak $250 \mathrm{ml}$ selama satu minggu.

Konsentrasi Pupuk urin kambing yang digunakan adalah $\mathrm{A}_{0}=0 \mathrm{ml} / \mathrm{l}$ (kontrol); $\mathrm{A}_{1=}$ $150 \mathrm{ml} / \mathrm{l} ; \mathrm{A}_{2}=175 \mathrm{ml} / \mathrm{l} ; \mathrm{A}_{3}=200 \mathrm{ml} / \mathrm{l} ; \mathrm{A}_{4}=$ $225 \mathrm{ml} / \mathrm{l} ; \quad \mathrm{A}_{5}=250 \mathrm{ml} / \mathrm{l}$. Perlakuan 
dilakukan dalam 2 minggu sekali yaitu pada 14,28,42, dan 56 HST.

Pengamatan meliputi tinggi tanaman, diameter batang, jumlah daun, dan bobot buah tomat yang dihasilkan. Pengamatan tinggi tanaman, diameter batang, dan jumlah daun dilakukan pada 20, 34, 48, 62 HST. Bobot buah dihitung dengan cara ditimbang kemudian dikonversikan ke hektar. Data yang diperoleh dianalisis secara statistic dengan menggunakan uji table sidik ragam dan dianalisis lebih lanjut dengan uji Duncan pada taraf 5\%.

\section{HASIL DAN PEMBAHASAN}

\section{Tinggi Tanaman}

Hasil analisis menunjukkan bahwa tidak ada pengaruh pupuk urin kambing yang difermentasikan terhadap tinggi tanaman (Tabel 1). Hal ini diduga karena tanah yang digunakan sudah memiliki kandungan hara yang tersedia langsung dan sesuai kebutuhan tanaman. Hal ini sesuai dengan pengujian praeksperimen yang dilakukan. Kandungan unsur $\mathrm{N}$ pada tanah yang digunakan sudah cukup tinggi (0.75\%), kandungan unsur $\mathrm{K}$ potensial sebesar 32 $\mathrm{mg} / 100 \mathrm{~g}$ tergolong kriteria sedang. Hakim et al., (1988) dalam Haryadi et al.,(2015) menyatakan bahwa unsur $\mathrm{N}$ berpengaruh terhadap peristiwa pembelahan dan pemanjangan sel. Unsur $\mathrm{N}$ juga membantu mengaktifkan sel-sel tanaman dan mempertahankan jalannya proses fotosintesis yang akan berpengaruh pada pertumbuhan tinggi tanaman. Kekurangan unsur $\mathrm{N}$ akan membatasi produksi protein dan bahan penting yang dibutuhkan dalam pembelahan sel (Hakim et al., 1986 dalam Haryadi et al., 2015). Selain unsur N, tersedianya unsur $\mathrm{K}$ yang cukup didalam tanah dapat mempengaruhi pertumbuhan tinggi tanaman. Sarief (1986) menyatakan bahwa unsur $\mathrm{K}$ berpengaruh dalam merangsang titik-titik pertumbuhan.

Tabel 1. Pengaruh kosentrasi pupuk Urin Kambing terhadap tinggi tanaman tomat

\begin{tabular}{llrrl}
\hline \multicolumn{1}{c}{$\begin{array}{c}\text { Perlakuan } \\
(\mathrm{ml} / \mathrm{l})\end{array}$} & $20 \mathrm{HST}$ & Rata - Rata Tinggi Tanaman $(\mathrm{cm})$ & \\
\hline $\mathrm{A}_{0}(0)$ & $29,06 \mathrm{a}$ & $34 \mathrm{HST}$ & $48 \mathrm{HST}$ & $62 \mathrm{HST}$ \\
$\mathrm{A}_{1}(150)$ & $29,30 \mathrm{a}$ & $31,45 \mathrm{a}$ & $50,47 \mathrm{a}$ & $122,61 \mathrm{a}$ \\
$\mathrm{A}_{2}(175)$ & $29,32 \mathrm{a}$ & $32,22 \mathrm{a}$ & $51,05 \mathrm{a}$ & $123,90 \mathrm{a}$ \\
$\mathrm{A}_{3}(200)$ & $29,58 \mathrm{a}$ & $32,24 \mathrm{a}$ & $51,45 \mathrm{a}$ & $124,46 \mathrm{a}$ \\
$\mathrm{A}_{4}(225)$ & $29,19 \mathrm{a}$ & $31,91 \mathrm{a}$ & $50,60 \mathrm{a}$ & $124,89 \mathrm{a}$ \\
$\mathrm{A} 5(250)$ & $29,15 \mathrm{a}$ & $31,51 \mathrm{a}$ & $50,48 \mathrm{a}$ & $123.07 \mathrm{a}$ \\
\hline
\end{tabular}

Ket. Angka yang diikuti huruf kecil yang sama tidak berbeda nyata menurut uji jarak berganda Duncan pada taraf nyata $5 \%$

\section{Diameter Batang}

Hasil analisis pengaruh pupuk urin kambing terhadap diameter tanaman tomat dapat dilihat pada Tabel 2. Tabel 2 menunjukkan bahwa diameter tertinggi diperoleh pada perlakuan $\mathrm{A}_{3}(200 \mathrm{ml} / \mathrm{l})$ ratarata mencapai $17,40 \mathrm{~mm}$ setelah $64 \mathrm{HST}$. Pada Tabel tersebut dapat dilihat pula bahwa antar perlakuan terjadi penambahan diameter batang yang tidak berbeda nyata baik antar perlakuan maupun dengan kontrol. Hal ini dikarenakan kandungan hara pada tanah yang digunakan sebelum penambahan pupuk urin kambing sudah mencukupi bagi tanaman. Kandungan $\mathrm{N}$ dan $\mathrm{K}$ pada tanah yang digunakan secara berturut-turut termasuk kriteria tinggi dan sedang. 
Gardner et al.,(2008) menyatakan bahwa penambahan atau pembesaran diameter batang disebabkan karena akumulasi fotosintat didaerah batang yang meningkat akibat dari proses metabolisme tanaman yang cukup karena unsur hara yang tersedia dalam jumlah cukup. Unsur $\mathrm{N}$ berpengaruh pada pembelahan sel dan pembesaran sel, sedangkan unsur $\mathrm{K}$ berperan untuk mempertahankan vigor tanaman (Lingga \& Marsono, 2013).

Tabel 2. Pengaruh kosentrasi pupuk Urin Kambing terhadap diameter batang tomat

\begin{tabular}{lcccc}
\hline $\begin{array}{c}\text { Perlakuan } \\
(\mathrm{ml} / \mathrm{l})\end{array}$ & \multicolumn{3}{c}{ Rata - Rata Diameter Batang $(\mathrm{mm})$} \\
& $20 \mathrm{HST}$ & $34 \mathrm{HST}$ & $48 \mathrm{HST}$ & $62 \mathrm{HST}$ \\
\hline $\mathrm{A}_{0}(0)$ & $5,23 \mathrm{a}$ & $9,28 \mathrm{a}$ & $13,86 \mathrm{a}$ & $17,25 \mathrm{a}$ \\
$\mathrm{A}_{1}(150)$ & $5,24 \mathrm{a}$ & $9,39 \mathrm{a}$ & $14,12 \mathrm{a}$ & $17,33 \mathrm{a}$ \\
$\mathrm{A}_{2}(175)$ & $5,6 \mathrm{a}$ & $9,44 \mathrm{a}$ & $14,12 \mathrm{a}$ & $17,35 \mathrm{a}$ \\
$\mathrm{A}_{3}(200)$ & $5,27 \mathrm{a}$ & $9,64 \mathrm{a}$ & $14,15 \mathrm{a}$ & $17,40 \mathrm{a}$ \\
$\mathrm{A}_{4}(225)$ & $5,26 \mathrm{a}$ & $9,29 \mathrm{a}$ & $13,92 \mathrm{a}$ & $17,23 \mathrm{a}$ \\
$\mathrm{A} 5(250)$ & $5,26 \mathrm{aa}$ & $9,29 \mathrm{a}$ & $13,92 \mathrm{a}$ & $17,21 \mathrm{a}$ \\
\hline
\end{tabular}

Ket : Angka yang diikuti huruf kecil yang sama tidak berbeda nyata menurut uji jarak berganda Duncan pada taraf nyata $5 \%$

\section{Jumlah Daun}

Pengaruh pemberian pupuk urin kambing terhadap jumlah daun yang diamati selama 62 HST dapat dilihat pada Tabel 3. Tabel 3 menunjukkan bahwa urin kambing dengan berbagai konsentrasi tidak berpengaruh secara nyata terhadap jumlah daun tanaman tomat pada 20,30,48,62 HST. Hal ini disebabkan karena kandungan nitrogen tanah yang tinggi sehingga penambahan pupuk urin kambing tidak memberikan respon terhadap jumlah daun, namun tidak toksik pada tanaman. Pertumbuhan daun merupakan bagian dari pertumbuhan vegetative. Pada pertumbuhan vegetative unsur hara yang banyak berperan adalah nitrogen. Nitrogen merupakan unsur hara makro yang dibutuhkan tanaman. Selain dibutuhkan dalam pembentukan protein, unsur nitrogen merupakan pembentuk struktur klorofil. Peran utama nitrogen pada tanaman adalah untuk merangsang pertumbuhan organ tanaman seperti batang, cabang, daun (Budhie,2010).

Tabel 3. Pengaruh kosentrasi pupuk Urin Kambing terhadap jumlah daun tomat

\begin{tabular}{lcccc}
\hline Perlakuan $(\mathrm{ml} / \mathrm{l})$ & \multicolumn{4}{c}{ Rata - Rata Jumlah Daun } \\
& $20 \mathrm{HST}$ & $34 \mathrm{HST}$ & $48 \mathrm{HST}$ & $62 \mathrm{HST}$ \\
\hline $\mathrm{A}_{0}(0)$ & $28,9 \mathrm{a}$ & $42,04 \mathrm{a}$ & $62,13 \mathrm{a}$ & $143,29 \mathrm{a}$ \\
$\mathrm{A}_{1}(150)$ & $28,9 \mathrm{a}$ & $42,89 \mathrm{a}$ & $62,28 \mathrm{a}$ & $144,43 \mathrm{a}$ \\
$\mathrm{A}_{2}(175)$ & $28,9 \mathrm{a}$ & $43,83 \mathrm{a}$ & $62,14 \mathrm{a}$ & $145,24 \mathrm{a}$ \\
$\mathrm{A}_{3}(200)$ & $29,3 \mathrm{a}$ & $44,56 \mathrm{a}$ & $63,4 \mathrm{a}$ & $147,58 \mathrm{a}$ \\
$\mathrm{A}_{4}(225)$ & $29,1 \mathrm{a}$ & $42,56 \mathrm{a}$ & $62,07 \mathrm{a}$ & $144,48 \mathrm{a}$ \\
$\mathrm{A} 5(250)$ & $28,71 \mathrm{a}$ & $42,56 \mathrm{a}$ & $62,4 \mathrm{a}$ & $144,39 \mathrm{a}$ \\
\hline
\end{tabular}

Ket: Angka yang diikuti huruf kecil yang sama tidak berbeda nyata menurut uji jarak berganda Duncan pada taraf nyata $5 \%$ 


\section{Bobot Buah Pertanaman (Kg) dan per Petak}

Tabel 4 menunjukkan bahwa pupuk urin kambing dengan berbagai konsentrasi mempengaruhi bobot buah pertanaman dan per petak.

Tabel 4. Pengaruh kosentrasi pupuk Urin Kambing terhadap bobot buah tomat

\begin{tabular}{lccc}
\hline \multirow{2}{*}{ Perlakuan $(\mathrm{ml} / \mathrm{l})$} & \multicolumn{3}{c}{ Rata - Rata bobot buah } \\
& Pertanaman $(\mathrm{kg})$ & Total $(\mathrm{kg} /$ petak $)$ & Total $(\mathrm{t} / \mathrm{ha})$ \\
\hline $\mathrm{A}_{0}(0)$ & $2,38 \mathrm{~b}$ & $9,36 \mathrm{~b}$ & 49,9 \\
$\mathrm{~A}_{1}(150)$ & $2,66 \mathrm{ab}$ & $10,23 \mathrm{ab}$ & 54,6 \\
$\mathrm{~A}_{2}(175)$ & $2,67 \mathrm{ab}$ & $10,33 \mathrm{ab}$ & 55,09 \\
$\mathrm{~A}_{3}(200)$ & $2,77 \mathrm{a}$ & $10,79 \mathrm{a}$ & 57,04 \\
$\mathrm{~A}_{4}(225)$ & $2,63 \mathrm{ab}$ & $10,23 \mathrm{ab}$ & 54,56 \\
$\mathrm{~A} 5(250)$ & $2,57 \mathrm{ab}$ & $10,21 \mathrm{ab}$ & 54,45 \\
\hline
\end{tabular}

Ket: Angka yang diikuti huruf kecil yang sama tidak berbeda nyata menurut uji jarak berganda Duncan pada taraf nyata $5 \%$

Tabel 4 menunjukkan bahwa pemberian pupuk urin kambing dengan berbagai konsentrasi mempengaruhi bobot buah pertanaman dan perpetak. Bobot buah tomat pada perlakuan $\mathrm{A}_{3}$ yaitu perlakuan dengan penambahan urin kambing dengan konsentrasi $200 \mathrm{ml} / \mathrm{l}$ menghasilkan rata-rata bobot buah pertanaman adalah $2,77 \mathrm{~kg}$ dan bobot buah perpetak $10,79 \mathrm{~kg}$, namun hasilnya tidak berbeda nyata dengan perlakuan penambahan pupuk urin kambing lainnya, dan berbeda nyata dengan bobot buah tomat tanpa penambahan pupuk urin kambing. Bobot terendah buah tomat dihasilkan oleh tanaman tanpa penambahan pupuk urin kambing yaitu 2,38 $\mathrm{kg}$ pertanaman dan 9,36 $\mathrm{kg}$ perpetak. Hal ini berbeda dengan penelitian yang dilaporkan oleh Sulardy \& Sani (2018) yang menyatakan bahwa penambahan pupuk urin kambing tidak berpengaruh terhadap produksi buah tomat. Namun sejalan dengan penelitian Nanda et al., (2016) yang menyatakan bahwa penambahan urin kambing dapat meningkatkan bobot buah jagung. Bobot jagung tertinggi yang diperoleh adalah 8.637,50 g sedangkan bobot terendahnya adalah pada perlakuan kontrol yaitu 7062,50 g per plot.

Dari Tabel 4 dapat dilihat bahwa semakin meningkat konsentrasi pupuk urin yang ditambahkan, semakin tinggi pula bobot buah tomat hingga konsentrasi 200 $\mathrm{ml} / \mathrm{l}\left(\mathrm{A}_{3}\right)$. Kemudian bobot buah tomat menurun pada perlakuan dengan konsentrasi $225 \mathrm{ml} / \mathrm{l}\left(\mathrm{A}_{4}\right)$ dan $250 \mathrm{ml} / \mathrm{l}\left(\mathrm{A}_{5}\right)$. Hal ini sesuai dengan pernyataan Risqiani et al.,(2007) yang mengatakan semakin tinggi konsentrasi pupuk cair yang diberikan, akan semakin tinggi pula kandungan hara yang diterima tanaman. Namun penambahan unsur hara yang berlebihan akan menyebabkan penurunan produksi tanaman. Peningkatan bobot buah pada tanaman yang diberi perlakuan dengan pupuk Urin Kambing diduga karena pengaruh unsur fosfor. Novizan (2002) mengatakan bahwa fosfor dapat 
merangsang pembentukan bunga, buah dan biji dan mampu mempercepat proses pemasakan buah. Kandungan fosfor pada tanah yang digunakan untuk penelitian ini sebelum ditambah perlakuan adalah $18 \mathrm{mg}$ dalam $100 \mathrm{~g}$ yang termasuk kedalam kriteria rendah. Sehingga penambahan pupuk urin kambing dapat meningkatkan kandungan fosfor tanah yang kemudian diserap oleh tanaman sebagai unsur hara. Fosfor berfungsi untuk merangsang pertumbuhan dan pemanjangan akar, sebagai bahan dasar protein, serta membantu dalam proses pemasakan biji dan buah (Sigit,2001 dalam Nanda et al.,2016). Kekurangan unsur fosfor akan menyebabkan ukuran dan bobot buah menjadi kecil. Dari Tabel 4 tersebut dapat dilihat juga bahwa penambahan pupuk urin kambing dapat meningkatkan bobot buah per hektar. Cahyono (2003) menyatakan bahwa dengan tersedianya media tanam dengan kandungan hara yang cocok maka bagian akar tanaman akan tumbuh lebih sempurna sehingga dapat meningkatkan seluruh pertumbuhan tanaman dan produksi hasil panen. Selain itu pemberian pupuk organik cair harus memperhatikan takaran, waktu, dan cara pemupukan agar diperoleh pengaruh terhadap pertumbuhan tanaman dan hasil panen yang optimal.

\section{KESIMPULAN DAN SARAN}

\section{Kesimpulan}

Pemberian berbagai konsentrasi pupuk urin kambing yang difermentasi tidak memberikan pengaruh nyata terhadap parameter pertumbuhan yaitu tinggi tanaman, diameter batang, dan jumlah daun. Namun memberikan pengaruh yang nyata terhadap bobot buah per tanaman dan per petak.

\section{Saran}

Berdasarkan hasil penelitian, untuk meningkatkan bobot buah tomat dapat diaplikasikan Pupuk urin kambing yang telah difermentasi. selain itu perlu penelitian lebih lanjut mengenai variasi kosentrasi pupuk urin kambing yang digunakan serta kultivar tanaman tomat yang berbeda.

\section{DAFTAR PUSTAKA}

Alvi, B., Ariyanti, M., Maxiselly, Y. 2018. Pemanfaatan beberapa jenis urin ternak sebagai pupuk organik cair dengan onsentrasi yang berbeda pada tanaman kelapa sawit (Elaeis guinensis jacq.) di pembibitan utama. Jurnal Kultivasi Vol 17(2): 622-627

Budhie, D.D.S. 2010. Aplikasi urin kambing peranakan etawa dan nasa sebagai pupuk organik cair untuk memicu pertumbuhan dan produksi tanaman pakan Legume Indgofera sp. Skripsi. Fakultas Peternakan IPB. Bogor.

Cahyono, Bambang. 2003. Teknik dan Strategi budidaya sawi hijau (pai Tsai). Yayasan Pustaka Nusantara. Yogyakarta.

Cahyono, Bambang. 2008. Tomat Usaha Tani dan Penanganan Pasca Panen (edisi revisi). Kanisius. Yogyakarta

Canene-adams, K., Clinton, S.K., King, J.L., Lindshiel, B.L., Wharton, C., Jeffery, E., Erdman, J.W.Jr. 2004. The Growth of Dunning R-3327TransplanTabel Prostate Adenocar cinoma in rats fed diets containing tomato, broccoli, lycopene, or receiving pinastric treatment. FASEB J. 18(591):4

Gardner, F.P., Pearce, B.R., Mitchell, R.L. 2008. Fisiologi Tanaman Budidaya. UI Press. Jakarta 
Haryadi, D., Yeti, H., Yoseva, S. 2015. Pengaruh pemberian beberapa jenis pupuk terhadap pertumbuhan dan produksi tanaman kalian (Brasica alboglaba). JOM Faperta Vol.2 No. 2

Kementrian Pertanian Repubik Indonesia. 2019. Data Lima Tahun Terakhir https://www.pertanian.go.id/home/in dex.php?show=repo\&fileNum $=292$ 28 Oktober 2019

Lingga, P., Marsono. 2013. Petunjuk penggunaan pupuk. Penebar Swadaya. Jakarta

Londra. 2008. Membuat pupuk cair bermutu dari limbah kambing. Warta Penelitian dan Pengembangan Pertanian Indonesia 30(6):5-7

Nanda,E., Mardiana, S., Pane, E. 2016. Pengaruh Pemberian berbagai konsentrasi Pupuk organik cair urin kambing terhadap pertumbuhan dan produksi tanaman jagung manis (Zea mays Saccharata). Agrotekma Vol 1(1) :24-37

Nasir, M.U., Hussain, F., Jabbar, S. 2015. Tomato processing, lycopene and health benefit : a review. OAJ Science Letters Vol 3(1):1-5.

Novizan. 2002. Petunjuk penggunaan pupuk yng efektif. Agromedia Pustaka. Jakarta

Risqiani, N., Ambarwati, Nussih, W.Y. 2007. Pengaruh dosis dan frekuensi pemberian pupuk organik terhadap pertumbuhan dan hasil buncis (Phaseolus vulgaris) dataran rendah. Jurnal ilmu tanah dan lingkungan Vol.7 No.1

Sarah, Hafnati Rahmatan, Suprianto. 2016. Pengaruh Pemberian Berbagai Konsentrasi urin kambing yang difermentasi terhadap pertumbuhan vegetative Lada (Piper nigrum).
Jurnal Ilmiah Pendidikan Biologi. Vol 1(1):1-9

Sarief, E.S. 1986. Kesuburan dan Pemupukan Tanah Pertanian. Pustaka Buana. Bandung

Sulardi T., Sany, A.M. 2018. Uji pemberian limbah padat pabrik kopi dan urin kambing terhadap pertumbuhan dan produksi tanaman tomat (Lycopersicum esculatum). Journal of Animal Science and Agronomy panca budi. Vol.3 No.2.

Surbakti, E.S., Berawi, K.N. 2016. Tomat (Lycopersicum esculatum Mill.)sebagai anti penuaan kulit. Majority Vol.5 No.3. 